\title{
HUBUNGAN ANTARA DISIPLIN KERJA DAN TUNJANGAN KINERJA DAERAH DENGAN KINERJA APARATUR UNTUK MENDUKUNG KESEJAHTERAAN SOSIAL DI KABUPATEN POHUWATO
}

\author{
Abdul Rahmat ${ }^{1}$ dan Mansur Kadir \\ Universitas Negeri Gorontalo \\ e-mail: abdulrahmat@ung.ac.id ${ }^{1)}$
}

\begin{abstract}
The purpose ofthis study was to determine the relationship between the Discipline of Work and Local Performance Allowance with the Administrative Performance for social welfare Atthe Department of Agriculture Crops and Food Security and the Environment Agency Pohuwato.
\end{abstract}

The method used in this studyare correlational survey method. This method was chosen as a technique designed to find out how much the relationship between the independent variables (indevendent variable) with the dependent variable (devendent variable). In this study, there are two independent variables and one dependent variable. The independent variables namely, labor discipline (X1) and the Regional Performance Allowance (TKD) (X2) while the dependent variable is the Administrative Performance $(Y)$.

Based on the results and discussion of this research can be concluded that: 1) Work Discipline has a significant influence on the performance of the officials at the Department of Agriculture Crops and Food Security and the Environment Agency Pohuwato, it can be seen in that the calculation of the product moment correlationr is counted 0.811 at the significance level (0.05), the price of 0,239 r table, the count $r>r$ of the table so that we can conclude the existence of a significant effect, while the effect kekutan criteria intervalarithmetic coefficient $r$ 0.811, which means relatively strong in fluence on the performance of the apparatus of labor discipline in the Department of Agriculture plantation sand Food Security and the Environment Agency Pohuwa to relatively strong. While $t$ of 0.957 and compare $d t$ table with a significance level of 0.044 (0.05) turns out $t$ count $>t$ table with the sense of the hypothesis is accepted which implies a very significant influence. 2) Regional Performance Allowance (TKD) has a significant influence on the Administrative Performance in the Department of Agriculture Crops and Food Security and the Environment Agency Pohuwa to, it can be seen in that the calculation of the product moment correlation $r$ counted was 0.922 at the significance level (0.05) pricer table is 0.098 then the count $r>r$ of the tables 0 that we can conclude the existence of a significant effect, while the effect kekutan criteria intervalarithmetic coefficient $r$ 0.922, which means relatively strong influence on the Performance TKD Apparatusas very strong. While $t$ of 0.957 and compare $d t$ table with a significance level of 0.044 (0.05) turns out $t$ count $>t$ table with the sense of the hypothesis is accepted which implies a very significant influence, 3) Relationship between Work Discipline and Regional Performance Allowance (TKD) is together have a significant effect on the Administrative performance in the Department of Agriculture Crops and Food Security and the Environment Agency Pohuwato. It can be seen in the streng $t$ 
hits Work Discipline and performance benefits area (TKD) jointlyon the performance of the apparatus, comparing the count $r$ with $r$ table it is known that $0.811>0.239$, the correlation strength both have quite a significant effect.

Keyword: Discipline, performance, andapparatus

\section{PENDAHULUAN}

Isu yang mengemuka dalam pengelolaan administrasi publik dewasa ini adalah kepemerintahan yang baik (good governance). Tuntutan gencar yang dilakukan oleh masyarakat kepada pemerintah untuk melaksanakan penyelenggaraan pemerintahan yang baik adalah sejalan dengan meningkatnya tingkat pengetahuan masyarakat, disamping adanya pengaruh globalisasi. Salah satu kunci keberhasilan suatu organsiasi dalam usaha pencapaian tujuan sangat ditentukan oleh kemampuan serta keterampilan pegawainya disamping kemampuan untuk menggerakkan dan mengarahkan bawahan atau pegawai dari pimpinan organisasi itu sendiri.Perkembangan lingkungan stratejik Nasional dan Internasional yang dihadapi dewasa ini mensyaratkan perubahan paradigma kepemerintahan pembaruan sistem kelembagaan dan peningkatan kompetensi sumberdaya manusia dalam penyelenggaraan pemerintahan dan pembangunan bangsa dan dalam hubungan antar bangsa untuk terselenggaranya kepemerintahan yang baik (good governance).

Dari hasil pengamatan menunjukkan bahwa faktor disiplin merupakan salah satu kendala yang dihadapi.Disiplin yang ada tidak timbul dari dalam jiwa sanubari aparatur tetapi hanya karena terpaksa. Oleh karena itu sudah waktunya tuntutan gencar yang dilakukan oleh masyarakat kepada pemerintah untuk melaksanakan penyelenggaraan pemerintah yang baik adalah sejalan dengan meningkatnya tingkat pengetahuan masyarakat disamping adanya pengaruh globalisasi. Oleh karena itu tuntutan tersebut merupakan hal yang wajar dan sudah seharusnya direspon oleh pemerintah dengan melakukan perubahanperubahan yang terarah pada terwujudnya penyelenggaraan pemerintahan yang baik.

Pemerintah Kabupaten Pohuwato sebagai suatu daerah otonom yang menangani kegiatan penyelenggaraan pemerintahan, pembangunan dan pelayanan masyarakat daerah, dituntut untuk memiliki kemampuan teknis administrative maupun tekhnis manajerial. Didalam melaksanakan otonomi, mengatur dan mengurus urusan yang menjadi tanggungjawab daerahnya, harus didukung oleh sumberdaya aparatur yang berkualitas. Salah satu hambatan yang cukup serius yang sering dihadapi oleh Pemerintah daerah dalam pelaksanaan pemerintahan dan pembangunan serta pemberian pelayanan kepada masyarakat adalah belum sesuainya kualitas kerja aparatur dengan apa yang diinginkan masyarakat, kurang tersedianya tenaga manusia dalam hal ini sumber daya manusia yang ahli dan sesuai dengan bidang kerjanya, aparatur bidang teknis masih didominasi aparat pendatang dari luar daerah sehingga pada hari libur tidak berada ditempat untuk antisipasi bila sewaktu-waktu dibutuhkan untuk melayani masyarakat, lambannya aparatur dalam menangani tugas-tugas yang dibebankan kepadanya, dan kondisi kapasitas administrative pegawai yang tidak memadai.

Di lingkungan Pemerintah Kabupaten Pohuwato, peranan pegawai baik secara individu maupun kelompok adalah sangat penting dan menentukan.Pegawai sebagai asset dan unsur utama dalam organisasi 
memegang peranan yang sangat menentukan dalam pencapaian tujuan organisasi. Agar Aparatur Pemerintah Kabupaten Pohuwato mampu menunjukkan kualitas kerja optimal sekaligus menepis kesan negatif tentang aparatur pemerintah selama ini, maka kemampuan aparatur perlu senantiasa ditingkatkan terutama dalam menyelenggarakan pemerintahan dan pelaksanaan pembangunan yakni dengan mengadakan pengembangan sumberdaya aparatur, misalnya dengan pendidikan dan pelatihan, mengikutsertakan pegawai dalam tugas belajar untuk mengikuti pendidikan formal, promosi jabatan dan kegiatan lainnya.

Berdasarkan hasil pengamatan bahwa dalam meningkatkan kinerja aparatur dan disiplin kerja maka Pegawai Negeri Sipil pada Dinas Pertanian Perkebunan dan Ketahanan Pangan serta Badan Lingkungan Hidup Kabupaten Pohuwato melakukan pengembangan sumberdaya manusia dengan cara Pendidikan dan Pelatihan (DIKLAT), mengikuti Kegiatan Non-Diklat, Tugas belajar, dan Promosi. Keempat cara pengembangan SDM tersebut adalah merupakan program yang diselenggarakan oleh pemerintah, dan bukan sifatnya mandiri. Berdasarkan analisa yang dilakukan bahwa selama ini belum pernah dilakukan evaluasi terhadap pegawai yang sudah melakukan pengembangan sumberdaya manusia, contohnya pegawai yang mengikuti diklat. Evaluasi diklat hanya dalam bentuk sertifikat dan dilakukan sesaat setelah pegawai selesai mengikuti diklat, tetapi tidak setelah pegawai kembali ke instansinya.Outcome dari diklat yaitu perubahan-perubahan yang terjadi pada pengetahuan, sikap dan prilaku alumni peserta diklat belum termonitor dan terevaluasi, sementara pegawai tetap harus bekerja.

Berdasarkan latar belakang masalah di atas rumusan masalah penelitian ini adalah: 1) Apakah terdapat hubungan antara disiplin kerja dengan Kinerja Aparatur?2) Apakah terdapat hubungan antara Tunjangan Kinerja Daerah (TKD) dengan Kinerja Aparatur? 3) Apakah terdapat hubungan secara bersama-sama antara disiplin kerja dan Tunjangan Kinerja Daerah ( TKD) dengan Kinerja Aparatur untuk mendukung kesejahteraan sosial?

Berdasarkan rumusan masalah di atas, maka penelitian ini dilakukan dengan tujuan: 1) Untuk mengetahui hubungan antara disiplin kerja dengan tunjangan kinerja aparatur, 2) Untuk mengetahui hubungan antara Tunjangan kinerja Daerah (TKD) dengan kinerja aparatur, 3) Untuk mengetahui hubungan secara bersama-sama antara disiplin kerja dan Tunjangan Kinerja Daerah (TKD) dengan kinerja aparatur untuk mendukung kesejahteraan sosial.

Hasil penelitian ini diharapkan dapat memberikan bantuan praktis dan nyata dalam meningkatkan disiplin kerja dan kinerja aparatur dan menjadi bahan masukan bagi para pegawai atau aparatur pemerintah untuk bekerja lebih efisien guna mencapai tujuan yang telah ditetapkan dalam organisasi. Bagi Dinas Pertanian Perkebunan dan Ketahanan Pangan Serta Badan Lingkungan Hidup Kabupaten Pohuwato, khususnya pemimpin dan pegawai atau aparat pemerintah di Dinas tersebut diharapkan dapat dijadikan sebagai masukan sehingga dapat meningkatkan kemampuan aparatur baik kemampuan profesionalnya, wawasannya, kepemimpinannya sehingga akan meningkatkan kinerja seorang aparatur.

Dalam penelitian ini ada beberapa tinjauan pustaka yaitu disiplin kerja, kinerja aparatur pemerintah dan tunjangan kinerja daerah.

Pertama Disipin Kerja, tidak dapat dipungkiri negara-negara yang telah maju semuanya dibangun dari dasar disiplin. Contoh kongkrit adalah Singapura 
dan Jepang. Orang-orang sukses memiliki sikap disiplin dalam menjalankan jadwal yang telah disusun. Sebaik apapun jadwal yang telah disusun tidak akan menghasilkan apapun jika tidak disiplin dengan pelaksanaannya (Setyaka, H. 2014 : 59). Orang sukses disamping disiplin, mengatur jadwal didasarkan pada : (1) fokus dalam aktivitas harian; (2) membuat jadwal aktivitas yang berimbang; (3) memiliki fleksibilitas; (4) mengurutkan jadwal berdasarkan prioritas; (5) menyiapkan waktu untuk santai dan; (6) menyediakan waktu untuk beribadah.

Doelhadi, (2001:55) menyatakan bahwa disiplin kerja pada dasarnya dapat diartikan sebagai suatu bentuk ketaatan dari perilaku seseorang dalam mematuhi ketentuan-ketentuan ataupun aturan-aturan tertentu yang berkaitan dengan pekerjaan yang diberlakukan dalam suatu organisasi atau perusahaan. Disiplin kerja karyawan akan membawa dampak positif bagi karyawan itu sendiri maupun organisasi.

Disiplin kerja yang tinggi akan mendorong seseorang merasa bertanggung jawab terhadap segala aspek pekerjaannya. Disiplin kerja dapat dipandang sebagai suatu kondisi yang ada dimana orang berperilaku secara sadar, suatu kondisi yang teratur, bebas dari perdebatan dan perselisihan paham juga berperilaku yang baik. Pembinaan disiplin sering dikaitkan pada pemberian hukuman bagi pelanggar peraturan, Greenberg dan Baron, (2003:76) menguraikan disiplin sebagai suatu proses pemberian hukuman melalui pemberian ganjaran yang tidak menyenangkan (seperti skors tanpa dibayar) terhadap perilaku yang tidak diinginkan, sedangkan menurut Mathisadan Jackson (2002:81), disiplin merupakan bentuk pelatihan yang menegakkan peraturan-peraturan perusahaan.

Hasibuan (2000) menyatakan bahwa disiplin yang baik mencerminkan besarnya rasa tanggung jawab seseorang terhadap tugas-tugas yang diberikan kepadanya. Hal ini mendorong gairah kerja, semangat kerja, dan terwujudnya tujuan perusahaan, karyawan, dan masyarakat. Berdasarkan pendapat beberapa ahli di atas, maka dapat ditarik kesimpulan bahwa disiplin kerja adalah suatu bentuk perilaku karyawan yang menunjukkan ketaatan, kepatuhan, dan ketertiban terhadap peraturan-peraturan organisasi atau perusahaan, baik yang tertulis maupun yang tidak tertulis yang berdasarkan atas kesadaran, kontrol diri, dan motivasi yang kuat dari karyawan untuk mencapai tujuan bersama.

Kedisiplinan muncul dari kesadaran tiap-tiap anggota kelompok untuk menaati aturan organisasi. Terbentuknya norma kelompok diikuti dengan sosialisasi atau pengenalan norma tersebut pada seluruh anggota kelompok, dapat dipastikan bahwa individu yang dilibatkan dalam pembuatan norma, tidak atau jarang melanggar norma-norma yang telah digariskan dalam kelompok (Walgito, 2001:12).

Kedua Kinerja Aparatur Pemerintah, istilah kinerja merupakan terjemahan unjuk kerja atau prestasi (Keban, 2004:90). Sementara itu pengertian kinerja itu sendiri menurut Wibowo (2008:99) "Berasal dari pengertian 'performance' yang memberikan pengertian sebagai hasil kerja atau prestasi kerja." Namun, sebenarnya Amstrong dan Baron menjelaskan bahwa kinerja merupakan hasil pekerjaan yang mempunyai hubungan kuat dengan tujuan strategis organisasi, kepuasan konsumen, dan memberikan kontribusi pada ekonomi. Atau dengan kata lain "Kinerja adalah sebagai hasil atau kerja dari suatu organisasi yang dilakukan oleh individu yang dapat ditunjukkan secara nyata dan dapat diukur."

Kinerja karyawan yang baik akan meningkatkan keuntungan perusahaan 
dan oleh karena itu ada persentase yang diberikan kepada karyawan. Secara tipikal bagian yang dibayarkan per tahun merupakan tambahan tunai atas gaji (Scott, Clathier dan Sriegel, 1961 dalam Duncan, 2004 : 262).

Osrolf, 1992; dikutip Luthans dan Peterson, 2002 dalam Suwatno H. Dan Priansa, J. (2011 : 195) menemukan bahwa ada hubungan signifikan positip antara perilaku kognitip karyawan dengan kinerja dan antara kepribadian dengan kinerja (Barrick dan Mount, 1991); antara emosi dengan kinerja (Staw, Sutton dan Pelled, 1994). Sedangkan untuk pengembangannya adalah cara untuk memotivasi dan meningkatkan keterampilan kerja, termasuk pemberian konseling pada perilaku karyawan dan menindak lanjuti dengan pengadaan pelatihan.

Kinerja seorang aparat pemerintah daerah adalah capaian yang diraih seorang aparat pemerintah daerah dalam pelaksanaan tugas pokoknya, dengan memperhitungkan lima dimensi kinerja yaitu dimensi kuantitas, kualitas, waktu, biaya, dan manfaat (Muhammad, F. 2008 : 228).

Mohi. E. (2013 : 67) dalam Amin Muhammad (2013) suatu pekerjaan yang bisa diselesaikan oleh satu orang dalam satu jam, kalau dibebankan kepada sepuluh orang maka kelarnya bisa sepuluh jam. Walaupun dari segi efisiensi benar tapi dari segi pengkaderan tidak benar karena tidak mendidik orang-orang atau generasi berikutnya untuk berbuat seperti itu. Siagian P.S.(2004 : 211 ) menyatakan tujuan dan harapan individual harus digabungkan dengan tujuan dan harapan organisasi, karena setiap orang akan melakukan interaksi dengan banyak pihak, baik di dalam maupun di luar organisasi.

KetigaTunjangan Kinerja Daerah, manusia memiliki tujuh sikap dasar untuk memotivasi dalam melakukan sesuatu, yaitu : (1) rasa pamrih. Setiap orang punya pamrih dan hanya tergerak untuk bertindak atau tertarik atau menerima sesuatu jika ada manfaat bagi dirinya; (2) ingin diperhatikan. Setiap orang ingin diperhatikan, didengar, dipahami sikapnya dan pendapatnya pada saat berbicara; (3) ingin diakui. Setiap orang ingin diakui keberadaaanya dengan meminta/dimintai pendapat dan saran-saranya; (4) tidak mau disalahkan. Setiap orang tidak mau disalahkan dan dipermalukan. Ingin didengar alasannya atas sikap dan hasil kerjanya; (5) Tidak senang dibantah. Penolakan setiap orang tidak senang dibantah, ditentang dan disanggah tentang pendapatnya dan sikapnya (membela diri); (6) tidak senang digurui. Setiap orang tidak senang digurui atau didikte dan disuruh tanpa alasan yang jelas, dan (7) senang dipuji. Setiap orang senang dipuji atas sikap, tindakan, pendapat serta prestasi yang telah dicapai atau dilakukannya (Wijaya, C.H. 2014 : 90).

Danim, S. (2006:42) menyatakan bahwa perilaku memberi insentif merupakan bagian integral dari upaya memotivasi karyawan, terutama dilihat dari dimensi eksternal. Manusia organisasional senantiasa ditantang oleh tuntutantuntutan ekonomi, non ekonomi, dan semi ekonomi. Ketiganya sangat dominan bagi motivasi seseorang. Dengan konsep tersebut dapat dinyatakan insentif ekonomi, insentif non ekonomi dan insentif semi ekonomi sebagai sasaran antara motivasi sehingga pada ujung-ujungnya akan meningkatkan produktivitas organisasi. Pada saat tertentu manusia terangsang dengan insentif ekonomi atau materi atau keuntungan-keuntungan ekonomi (contoh uang, barang yang dinilai dengan uang, barang-barang lain). Pada saat lain terangsang dengan dengan insentif non material (pujian, penempatan yang sesuai, promosi, rekreasi, dll) atau keuntungan-keuntungan semi material (piagam penghargaan, undangan khusus, tanda kenang-kenangan). Wingfield, B. Dan Berry, J. 2006: 9 
menyatakan bahwa untuk mempertahankan dan memberikan kepuasan kerja yang tinggi kepada karyawan sebaiknya mengimplementasikan tiga $\mathrm{R}$, yaitu respect (menghormati), recogonition (mengakui keberadaan) dan reward (menghargai). Reward atau menghargai adalah balas jasa ekstra yang harus diupayakan setelah respect dan recognition sehingga karyawan merasa bernilai dan mau bekerja keras memperhatikan perusahaan dan bekerja lembur, walaupun merupakan terkecil dari seluruh upaya mempertahankan karyawan.

Dasar hukum ini didukung oleh PP Nomor 105 Tahun 2000 Tentang Pengelolaan dan Pertanggung jawaban Keuangan Daerah, yaitu pada Pasal 29 ayat (2) di mana diatur Pegawai Negeri Sipil Daerah dapat diberikan tambahan penghasilan berdasarkan pertimbangan yang obyektif dengan memperhatikan kemampuan keuangan daerah dan memperoleh persetujuan DPRD sesuai dengan ketentuan peraturan perundang-undangan yang berlaku. Lebih detail lagi di dalam Penjelasan pasal 29 ayat (2) diterangkan bahwa tambahan penghasilan diberikan dalam rangka peningkatan kesejahteraan pegawai, berdasarkan prestasi kerja, tempat bertugas, dan kelangkaan profesi. Pemberian TKD di Provinsi Gorontalo bertujuan untuk meningkatkan motivasi pejabat negara, pegawai negeri sipil, dan tenaga kontrak untuk bekerja di atas standar. Dengan demikian besaran TKD tidak selalu sama setiap bulannya, melainkan sesuai dengan capaian kinerja menurut klasifikasi uraian tugas.

\section{METODE PENELITIAN}

Lokasi penelitian ini adalah di Kantor Dinas Pertanian, Perkebunan dan Ketahanan Pangan dan Badan Lingkungan Hidup Kabupaten Pohuwato . Waktu penelitian dilaksanakan selama 3 bulan, dimulai dari bulan Agustus hingga bulan Oktober 2014.

Metode penelitian yang digunakan dalam penelitian ini adalah metode survei korelasional.Metode ini dipilih sebagai suatu teknik yang dirancang untuk mengetahui seberapa besar hubungan antara variabel bebas (indevendent variable) dengan variabel terikat (devendent variable).Dalam penelitian ini terdapat dua variabel bebas dan satu variabel terikat. Variabel bebas yaitu, disiplin kerja $\left(\mathrm{X}_{1}\right)$ dan Tunjangan Kinerja Daerah (TKD) $\left(\mathrm{X}_{2}\right)$ sedangkan variabel terikat adalah Kinerja Aparatur (Y).

Desain kostelasi antar variable dalam penelitian ini sebagai berikut:

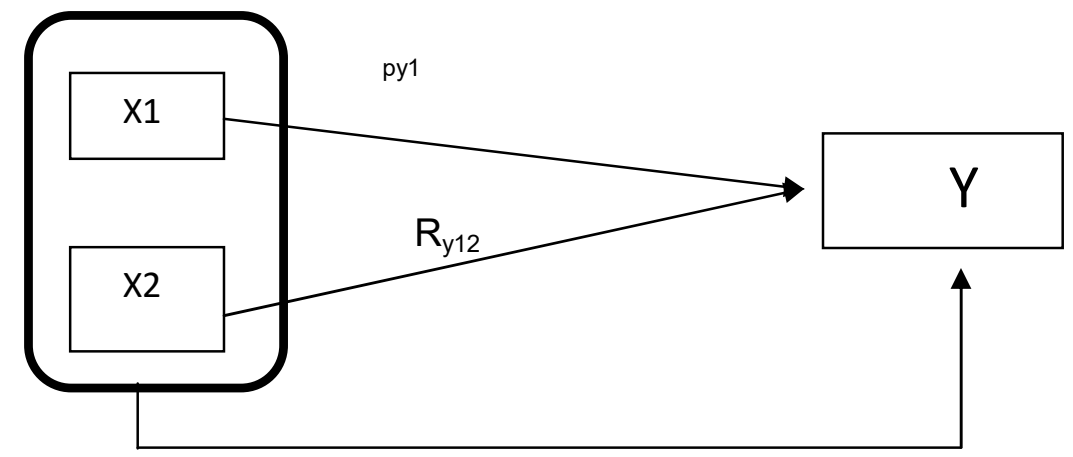

Dimana $\mathbf{Y}=$ Kinerja Aparatur, $\mathbf{X 1}=$ disiplin kerja, $\mathbf{X} \mathbf{2}=$ Tunjangan Kinerja Daerah (TKD).

Memperhatikan jenis variabel penelitian yang dipilih yakni ; Kinerja Aparatur $(Y)$, Disiplin Kerja $\left(\mathrm{X}_{1}\right)$ dan Tunjangan Kinerja Daerah (TKD) $\left(\mathrm{X}_{2}\right)$ maka 
peneliti melakukan pengembangan variabel melalui kajian teoritik ketiga variabel untuk selanjutnya melakukan penyusunan instrumen penelitian.

Adapun yang menjadi populasi dalam penelitian ini adalah Pegawai Dinas yang bertugas di Dinas Pertanian, Perkebunan dan Ketahanan Pangan serta Badan Lingkungan Hidup yang berjumlah 93 orang yang terdiri dari pejabat struktural sebanyak 30 orang dan staff pegawai 63 orang.

Sampel dalam penelitian ini adalah 93 orang. Rincian sampelnya terdiri dari: pejabat struktural berjumlah 30 orang, yakni: Kepala bidang 7 orang; Kepala Seksi/Kepala Sub Seksi 19 orang; dan staf 63 orang serta Staff pegawai berjumlah 63 orang yang berasal dari staff seksi Dinas Pertanian Perkebunan Ketahanan Pangan dan staff subseksi Badan Lingkungan Hidup.

Penelitian ini menggunakan metode penilitian deskriptif dengan pendekatan kuantitatif.Penelitian ini tidak hanya terbatas pada pengumpulan dan penyusunan data tetapi meliputi analisis dan interpretasi data yang telah dikumpulkan dan segala sesuatu dalam penelitian ini ditentukan dari hasil pengumpulan data yang mencerminkan keadaan yang sesungguhnya di lapangan.

Setelah data dikumpulkan, maka dilanjutkan dengan pengolahan data dengan metode sebagai berikut:

\section{Tabel frekwensi kategorik}

Tabel frekwensi kategorik disebut juga tabel data tunggal. Kedua Variabel yang tertera berdasarkan semua indikator yang telah dituangkan dalam kuisioner akan dianalisis secara kuantitatif. Data yang diperoleh dari hasil kuesioner adalah data interval yang akan disajikan dalam bentuk tabel distribusi frekwensi kategorik frekwensi jawaban dari masing-masing pertanyaan pada kuisioner. Untuk mempermudah penulis dalam menganalisis data, maka menggunakan statistik sederhana yaitu persentase (\%). Menurut Moh. Nazir (2005) penghitungan data dalam persen dilakukan dengan rumus sebagai berikut:

$$
P=\frac{f}{N} \times 100 \%
$$

Dimana $\mathbf{P}=$ Persentase, $\mathbf{F}=$ Frekwensi jawaban, $\mathbf{N}=$ Jumlah Responden

\section{Koefisien korelasi product moment}

Perhitungannya dengan menggunakan rumus sebagai berikut:

$$
r_{x y}=\frac{n \sum X Y-\left(\sum X\right)\left(\sum Y\right)}{\sqrt{\left\{n \sum X^{2}-\left(\sum X\right)^{2}\right\}\left\{n \sum Y^{2}-\left(\sum Y\right)^{2}\right\}}}
$$

Dimana $\mathbf{r x y}=$ Koefisien korelasi product moment, $\mathbf{n}=$ Banyaknya sampel, $\Sigma \mathbf{X}=$ Jumlah seluruh skor " $\mathrm{X}$ ", $\Sigma \mathbf{Y}=$ Jumlah seluruh skor " $Y$ ", $\Sigma \mathbf{X Y}=$ Jumlah hasil kali skor "X" dan skor "Y"

\section{Uji signifikan}

Uji signifikan digunakan untuk menentukan apakah hipotesis diterima atau ditolak. Pengambilan keputusan menggunakan angka pembanding $t$ tabel dengan kriteria sebagai berikut:

- Jika t hitung > t table $\mathrm{HO}$ ditolak; $\mathrm{H} 1$ diterima

- Jika t hitung< $\quad \mathrm{t}$ table $\mathrm{HO}$ diterima; $\mathrm{H} 1$ ditolak.

Rumus yang digunakan adalah:

$$
\mathrm{T}_{\text {hitung }}=\frac{\sqrt[r]{n}-r^{2}}{\sqrt{1}-r^{2}}
$$




\section{HASIL DAN PEMBAHASAN}

\section{Hasil Penelitian}

\section{Uji Reliabilitas}

Uji coba instrumen yang dilakukan pada 93 orang responden yang semuanya merupakan populasi dari penelitian yang dijadikan sampel penelitian. Pengujian reliabilitas tiap butir yang digunakan adalah analisis item/butir. Instrumen yang digunakan untuk menghitung reliabilitas adalah instrumen yang valid saja. Nilai Reliabilitas dapat dihitung dengan menggunakan Rumus sebagai berikut:

$$
r_{t t}=\left(\frac{k}{k-1}\right)\left(1-\frac{\sum S_{i}^{2}}{S_{t}^{2}}\right)
$$

Dimana $\mathbf{R}_{\mathbf{t t}}=$ Reliabilitas instrumen, $\mathrm{K}=$ Butir soal yang valid, $\sum S_{i=}^{2}$ Jumlah Varians Butir, $S_{t}^{2}=$ Varians Total

Adapun hasil pengolahan data dengan program exel (dengan bantuan program SPSS versi 17) semua variabel realibel hasil perhitungan dapat dilihat pada lampiran untuk rekapitulasi hasil perhitungan di bawah :

Tabel 1

Reliabilitas Variabel Disiplin Kerja $\left(\mathbf{X}_{1}\right)$

\begin{tabular}{cc}
\hline $\begin{array}{c}\text { Cronbach's } \\
\text { Alpha }\end{array}$ & N of Items \\
\hline 0,924 & 28 \\
\hline
\end{tabular}

Tabel 2

Reliabilitas Variabel Tunjangan Kinerja Daerah $\left(X_{2}\right)$

\begin{tabular}{cc}
$\begin{array}{c}\text { Cronbach's } \\
\text { Alpha }\end{array}$ & N of Items \\
\hline 0,923 & 26 \\
\hline
\end{tabular}

Tabel 3

Reliabilitas Variabel Kinerja Aparatur (Y)

\begin{tabular}{cc}
$\begin{array}{c}\text { Cronbach's } \\
\text { Alpha }\end{array}$ & N of Items \\
\hline 0,948 & 40
\end{tabular}

\section{Pengujian Persyaratan Analisis Dengan Uji Asumsi Klasik}

a. Uji Normalitas

Pengujian asumsi klasik dengan menggunakan regresi berganda uji normalitas dimaksudkan untuk menguji variabel bebas $(X)$ dan data variabel terikat (Y) pada persamaan regresi yang dihasilkan apakah berdistribusi normal atau berdistribusi tidak normal. Persamaan regresi dikatakan baik jika mempunyai data variabel bebas dan data variabel terikat berdistribusi normal atau tidak sama sekali. Hal ini bisa diketahui dengan dua cara yakni cara statistik 
dan cara grafik histogram.

\section{1) Cara statistik}

Dengan persamaan regresi statistik pada uji normalitas maka harus diketahui terlebih dahulu melalui nilai kemiringan kurva (skewness $=a 3$ ) atau nilai kruncingan kurva (kurtosis $=$ a4) diperbandingkan dengan nilai $Z$ tabel, dengan ketentuan analisis sebagai berikut berdasarkan ketentuan analisis: a) Veriabel (bebas atau terikat) berdistribusi normal jika Z hitung (Za3 atau Za4) $<Z$ tabel. b) Variabel berdistribusi tidak normal jika Z hitung (Za3 atau Za4) $>$ Z tabel. Untuk mengetahui apakah dengan menggunakan uji statistik pada distribusi normalitas sebagaimana hasil olah data yang disajikan berikut (lihat lampiran uji normalitas):

Nilai uji pada variabel Disiplin kerja diketahui Z hitung (Za3 atau Za4) $<$ Z tabel yaitu $-0,757<0,495$, maka variabel $X_{1}$ berdistribusi normal. Kemudian, variabel Tunjangan Kinerja Daerah (TKD) diketaui Z hitung (Za3 atau Za4) $<Z$ tabel yakni memiliki perbandingan $0,018<0,495$, maka dinyatakan berdistribusi normal. Dan, varibel terikat (Y) Kinerja Aparatur memiliki perbandingan $Z$ hitung (Za3 atau Za4) < Z tabel, yakni 0,052 < 0,495, maka dinyatakan berdistribusi normal.

\section{2) Cara Grafik Histogram}

Cara grafik histogram dalam menentukan suatu data berdistribusi normal atau tidak, cukup membandingkan antara data riil/nyata dengan garis kurva yang terbentuk, apakah mendekati normal atau memang normal sama sekali. Jika data riil membentuk garis kurva cenderung tidak berdistribusi normal, dan sebaliknya. Cara grafik histogram lebih sesuai untuk data yang relatif banyak dan tidak cocok untuk banyak data yang sedikit karena interpretasinya dapat menyesatkan. Untuk mengetahui hasil (dengan bantuan SPSS) diketahui sebagaimana berikut ini:

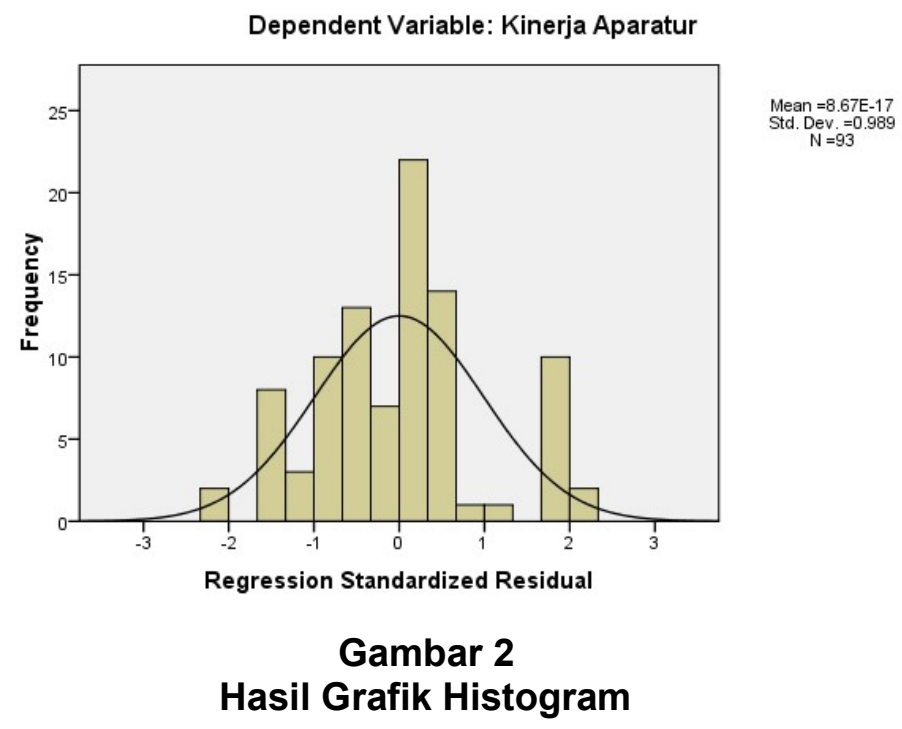

Dari hasil grafik histogram di atas, didapatkan garis kurva normal berarti data yang diteliti berdistribusi normal.Maka dari itu hasil analisis data pada uji normalitas ini telah memenuhi analisis prasyarat yang diajukan untuk kemudian dilanjutkan pada pengujian hipotesis dan uji lainnya. 


\section{b. Uji Multikolinieritas}

Uji ini dimaksudkan untuk mendeteksi gejala korelasi antara variabel independen yang satu dengan variabel independen yang lain. Pada model regresi yang baik seharusnya tidak terdapat korelasi di antara variabel independen. Uji Multikolinieritas dapat dilakukan dengan 2 cara yaitu dengan melihat VIF (Variance Inflation Factors) dan nilai tolerance. Jika VIF > 10 dan nilai tolerance < 0,10 maka terjadi gejala Multikolinieritas. Hasil olah data sebagaimana berikut ini:

Tabel 4

Hasil Uji Multikolenieritas

\begin{tabular}{|c|c|c|c|c|}
\hline No. & $\begin{array}{c}\text { Variabel } \\
\text { Independen }\end{array}$ & Tolerance & VIF & Keterangan \\
\hline 1 & Disiplin Kerja & 0,920 & 1,087 & $\begin{array}{c}\text { Tidak terjadi } \\
\text { Multikolenieritas }\end{array}$ \\
\hline 2 & $\begin{array}{l}\text { Tunjangan } \\
\text { Kinerja Daerah }\end{array}$ & 0,920 & 1,087 & $\begin{array}{c}\text { Tidak terjadi } \\
\text { Multikolenieritas }\end{array}$ \\
\hline
\end{tabular}

Sumber: Data Primer diolah, 2014.

Dari data tabel tersebut dapat diketahui bahwa syarat untuk lolos dari uji multikolinieritas sudah terpenuhi oleh seluruh variabel independen yang ada, yaitu nilai tolerence yang tidak kurang dari 0,10 dan nilai VIF yang tidak lebih dari 10. Maka dari itu dapat disimpulkan bahwa seluruh variabel independen yang digunakan dalam penelitian ini tidak berkorelasi antara variabel independen satu dengan variabel independen yang lain. Sehingga dapat disimpulkan tidak terjadi multikolenieritas.

\section{c. Uji Heteroskedastisitas}

Uji Heteroskedastisitas bertujuan untuk menguji apakah dalam model regresi terjadi ketidaksamaan variance dari residual satu pengamatan ke pengamatan yang lain tetap, atau disebut homoskedastisitas. Model regresi yang baik adalah yang homoskedastisitas, tidak heteroskedastisitas. Heteroskedastisitas ditandai dengan adanya pola tertentu pada grafik scatterplot.Jika titik-titik yang ada membentuk suatu pola tertentu yang teratur (bergelombang), maka terjadi heterokedastisitas.Jika tidak ada pola yang jelas, titik-titik menyebar di atas dan di bawah angka nol pada sumbu $Y$, maka tidak terjadi heterokedastisitas.Maka untuk lebih jelas hasil olah data sebagaimana berikut ini:

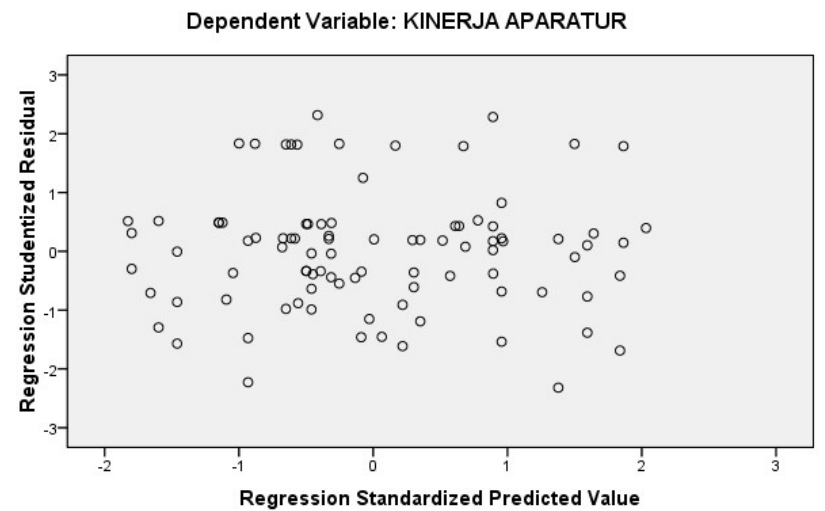

Gambar 3 


\section{Uji Kurva Penyebaran P-Plot}

Berdasarkan grafik hasil gambar di atas dapat dilihat bahwa distribusi data tidak teratur dan tidak membentuk pola tertentu, serta tersebar di atas dan bawah angka 0 pada sumbu $Y$, sehingga dapat disimpulkan bahwa pada model regresi ini tidak terjadi masalah heteroskedasitas.

\section{Pengujian Hipotesis}

\section{a. Uji Determinasi (Uji $\mathbf{R}^{2}$ )}

Uji determinasi digunakan untuk mengukur seberapa jauh kemampuan model menjelaskan variasi dependen.Apabila nilai koefisien determinasi dalam model regresi semakin kecil (mendekati nol) berarti semakin kecil pengaruh semua variabel independen terhadap variabel dependen. Dengan kata lain nilai $\mathrm{R}^{2}$ yang nilai kecil berarti kemampuan semua variabel dalam menjelaskan variabel dependen sangat terbatas. Sebaliknya apabila nilai $\mathrm{R}^{2}$ semakin mendekati $100 \%$ berarti semua variabel independen dalam model memberikan hampir semua imformasi yang diperlukan untuk memprediksi variabel dependennya atau semakin besar pengaruh semua variabel independen terhadap variabel dependennya.Hasil koefisien determinasi $\left(R^{2}\right)$ Disiplin Kerja dan Tunjangan Kinerja Daerah (TKD) dengan Kinerja Aparatur dapat dilihat pada tabel berikut ini:

Tabel 5

Koefisien Determinasi Disiplin Kerja dan Tunjangan Kinerja Daerah (TKD) dengan Kinerja Aparatur

\begin{tabular}{ccc}
\hline $\begin{array}{c}\text { Disiplin Kerja dan } \\
\text { Tunjangan Kinerja Daerah } \\
\text { (TKD) dengan Kinerja } \\
\text { Aparatur Guru }\end{array}$ & $\begin{array}{c}\text { Koefisien } \\
\text { Determinasi }\left(\mathbf{R}^{2}\right)\end{array}$ & Keterangan \\
\hline$X-Y$ & 0,031 & $\begin{array}{c}\text { Persamaan } \\
X 100 \%\end{array}$ \\
\hline
\end{tabular}

Sumber: Data Primer yang diolah, 2014.

Berdasarkan hasil pengujian yang ada pada tabel di atas dapat diketahui bahwa Adjusted Determination Coefficient $\left(R^{2}\right)$ sebesar 0,031 yaitu lebih dari nol dan kurang dari satu yang berarti variabilitas disiplin kerja dan tunjangan kinerja daerah (TKD) yang dapat dijelaskan oleh variabilitas variabel kinerja aparatur sebesar $0,4 \%$, sehingga variabel Disiplin Kerja dan Tunjangan Kinerja Daerah (TKD) dengan Kinerja Aparatur mempunyai kemampuan dalam menerangkan dan memprediksi variabel kinerja sangat terbatas.

\section{b. Uji Simultan (Uji F)}

Uji $\mathrm{F}$ digunakan untuk mengetahui ada tidaknya pengaruh simultan variabel-variabel independen terhadap variabel dependen. Kriteria pengujian yang digunakan adalah jika probability value $(p$ value $)<0,05$, maka Ha diterima dan jika $p$ value $>0,05$, maka Ha ditolak. Uji $F$ dapat pula dilakukan dengan membandingkan nilai $F_{\text {hitung }}$ dan $F_{\text {tabel.Jika }} F_{\text {hitung }}>F_{\text {tabel, }}$, maka Ha diterima.Artinya, secara statistik daya yang ada dapat membuktikan bahwa semua variabel independen $\left(\mathrm{X}_{1}, \mathrm{X}_{2}\right)$ berpengaruh terhadap variabel dependen $(\mathrm{Y})$.Jika $\mathrm{F}_{\text {hitung }}<$ $F_{\text {tabel, }}$ maka ditolak.Artinya, secara statistik daya yang ada dapat membuktikan bahwa semua variabel independen $\left(\mathrm{X}_{1}, \mathrm{X}_{2}\right)$ tidak berpengaruh terhadap variabel 
dependen (Y).

Tabel 6

Hasil Uji Simultan (Uji F)

\begin{tabular}{rccc}
\hline $\mathbf{N}$ & $\mathbf{F}$ (hitung) & $\mathbf{F}$ (tabel) & Kesimpulan \\
\hline $\mathbf{9 3}$ & 0,044 & 0,957 & Positif \\
\hline
\end{tabular}

Sumber: Data primer diolah, 2014.

Pada tabel di atas dapat dilihat bahwa berdasarkan hasil uji simultan (Uji F) menunjukan bahwa $F_{\text {hitung }}<\mathrm{F}_{\text {tabel }}=0,042<0,957$ maka hasil data tersebut dapat dinyatakan $\mathrm{Ha}$ ditolak. Artinya, secara statistik daya yang ada dapat membuktikan bahwa semua variabel yakni variabel $(X)$ disiplin kerja dan tunjangan kinerja daerah (TKD) tidak mempunyai pengaruh signifikan pada variabel $(Y)$ yakni kinerja aparatur.

\section{c. Uji Parsial (Uji t)}

Uji parsial (Uji t) digunakan untuk mengetahui pengaruh masing-masing variabel independen terhadap variabel dependen. Kriteria pengujian yang digunakan adalah jika $p$ value $<0,05$, maka Ha diterima dan jika $p$ value $>0,05$, maka Ha ditolak. Kemudian, hasil olah data SPSS uji parsial (uji t) berikut ini:

Tabel 7

Hasil Uji Parsial (Uji t)

\begin{tabular}{lcc}
\hline \multicolumn{1}{c}{ Variabel } & $\mathbf{t}$ (hitung) & $\mathbf{t}$ (tabel) \\
\hline Disiplin Kerja & 0,239 & 0,811 \\
Tunjangan Kinerja & 0,098 & 0,922 \\
Daerah (TKD) & &
\end{tabular}

Sumber: Data primer diolah, 2014.

Berdasarkan tabel di atas dapat disimpulkan bahwa nilai $t$ (hitung) pada variabel Disiplin Kerja 0,239 dengan nilai probabilitas (disamakan dengan nilai t (tabel)) adalah 0,811 atau 81,1\% (persamaan koefisiensi determinasi) di atas $5 \%$. Dan, nilai $t$ (hitung) pada variabel Tunjangan Kinerja Daerah adalah 0,098 dengan nilai probabilitas 0,922 atau $92,2 \%$ di atas $5 \%$. Hal ini dapat disimpulkan bahwa variabel Disiplin Kerja memiliki nilai $t$ (hitung) $=0,239>0,05$ atau $5 \%$ (persamaan nilai probabilitas), maka Ho ditolak. Sedangkan, variabel Tunjangan Kinerja Daerah memiliki nilai $t$ (hitung) $=0,098>0,05$ atau $5 \%$, maka Ho ditolak.

\section{Pembahasan}

\section{Hubungan Antara Disiplin Kerja dengan Kinerja Aparatur}

Hipotesis yang pertama yang diujikan adalah terdapatnya hubungan antara disiplin kerja dengan kinerja aparatur.Dari hasil analisa dengan SPSS Versi. 17 (lihat lampiran) dapat dijelaskan bahwa $\mathrm{F}$ hitung 102.477 lebih besar dari $F$ tabel atau juga nilai signifikansi uji $F$ lebh kecil dari nilai alfa 0,05 yang artinya regresi mempunyai pengaruh yang sangat signifikan. Sedangkan konstantanya 22,519 yang artinya jika variabel disiplin kerja meningkat satu point maka variabel kinerja aparatur akan meningkat 22,619 point.

Dari hasil perhitungan dapat disimpulkan bahwa koefisien diterminasi 0,031 yang artinya kinerja aparatur disumbang oleh disiplin kerja sebesar $3,1 \%$, melalui model persamaan regresinya.Kekuatan pengaruh disiplin kerja terhadap kinerja aparatur, berdasarkan analisis perhitungan korelasi product moment bahwa $r$ hitungnya adalah 0,811 pada taraf signifikansi $(0.05)$ harga $r$ tabel 
sebesar 0,239 maka $r$ hitung $>r$ tabel sehingga dapat disimpulkan adanya pengaruh yang sangat signifikan, adapun kekutan pengaruh berdasarkan kriteriainterval koefisien $r$ hitung 0,811 tergolong kuat yang artinya pengaruh disiplin kerja terhadap kinerja aparatur tergolong kuat. Sedangkan t hitung sebesar 0,957 dan dibandingkan $t$ tabel sebesar $(0,044)$ dengan taraf signifikansi (0.05) ternyata $t$ hitung $>$ dari $t$ tabel dengan arti hipotesis diterima yang menyatakan adanya pengaruh yang signifikan.

\section{Tabel 8}

Hasil Perhitungan Uji Korelasi Product Moment dan t Hitung

\begin{tabular}{ccccc}
\hline \multirow{2}{*}{$\mathbf{N}$} & \multirow{2}{*}{ (hitung) } & \multirow{2}{*}{ (Hitung) } & \multicolumn{2}{c}{ Signifikansi $\mathbf{0 . 0 5}$} \\
\cline { 4 - 5 } & & $\mathbf{r}$ tabel & $\mathbf{t}$ table \\
\hline 93 & 0,811 & 0,957 & 0,239 & 0,044 \\
\hline
\end{tabular}

Sumber: Data primer yang diolah, 2014.

Pengujian ini menunjukan adanya pengaruh yang signifikan sedangkan kekuatan pengaruhnya sebesar $3,1 \%$ hal ini juga berarti bahwa semakin baik disiplin kerja maka kinerja aparatur semakin baik dalam melaksanakan tugas atau kerja. Kondisi demikian bisa disebabkan oleh multifaktor maka bagi pimpinan dalam membangun iklim kerja yang kondusif harus memperhatikan item-item evaluasi lainnya.

\section{Hubungan Antara Tunjangan Kinerja Daerah (TKD) dengan Kinerja Aparatur}

Hipotesis kedua yang diujikan adalah terdapatnya hubungan Tunjangan Kinerja Daerah (TKD) dengan Kinerja Aparatur. Pengujian dimaksudkan untuk mengetahui apakah persamaan regresi yang diperoleh sama atau hampir sama dengan model regresi berganda. Dari hasil analisa dengan SPSS Versi. 17 (lihat lampiran) dapat dijelaskan bahwa $\mathrm{F}$ hitung 102.477 lebih besar dari $\mathrm{F}$ tabel atau juga nilai signifikansi uji $\mathrm{F}$ lebh kecil dari nilai alfa 0,05 yang artinya regresi mempunyai pengaruh yang sangat signifikan. Sedangkan konstantanya 22,519 yang artinya jika variabel tunjangan kinerja daerah meningkat satu point maka variabel kinerja aparatur akan meningkat 22,519 point.

Dari hasil perhitungan dapat disimpulkan bahwa koefisien diterminasi 0,031 yang artinya TKD disumbang oleh Kinerja Aparatur sebesar 3,1\%, melalui model persamaan regresinya. Kekuatan pengaruh variabel Tunjangan Kinerja Daerah (TKD) terhadap Kinerja Aparatur, berdasarkan analisis perhitungan korelasi product moment bahwa $r$ hitungnya adalah 0,922 pada taraf signifikansi (0.05) harga $r$ tabel sebesar 0,098 maka $r$ hitung $>$ dari $r$ tabel sehingga dapat disimpulkan adanya pengaruh signifikan, adapun kekuatan pengaruh berdasarkan kriteria interval koefisien $r$ hitung 0,922 tergolong kuat yang artinya pengaruh Tunjangan Kinerja Daerah (TKD) memiliki pengaruh yang cukup signifikan. Sedangkan $t$ hitung sebesar0,957 dan dibandingkan t tabel sebesar $(0,044)$ dengan taraf signifikansi $(0.05)$ ternyata t hitung $>$ dari t tabel dengan arti hipotesis diterima yang menyatakan adanya pengaruh yang signifikan.

\section{Tabel 9}

Hasil Perhitungan Uji Korelasi Product Moment dan t Hitung

\begin{tabular}{ccccc}
\hline \multirow{2}{*}{$\mathbf{N}$} & \multirow{2}{*}{$\mathbf{r}$ (hitung) } & \multirow{2}{*}{ (Hitung) } & \multicolumn{2}{c}{ Signifikansi $\mathbf{0 . 0 5}$} \\
\cline { 3 - 5 } & & $\mathbf{r}$ tabel & $\mathbf{t}$ tabel \\
\hline 93 & 0,922 & 0,957 & 0,098 & 0,044 \\
\hline
\end{tabular}

Sumber: Data primer yang diolah, 2014. 
Pengujian ini menunjukan adanya pengaruh yang signifikan sedangkan kekuatan pengaruhnya sebesar 3,1\% hal ini juga berarti bahwa semakin banyak tunjangan kinerja daerah berarti kinerja aparatur semakin baik.

\section{Pengujian Hipotesis Hubungan Secara Bersama-sama Antara Disiplin Kerja dan Tunjangan Kinerja Daerah (TKD) dengan Kinerja Aparatur.}

Hipotesis yang ketiga yang diujikan adalah terdapatnya hubungan secara bersama-sama antara disiplin kerja dan Tunjangan Kinerja Daerah (TKD) dengan kinerja aparatur.Pengujian dimaksudkan untuk mengetahui probabilitas keliru, apakah persamaan regresi yang diperoleh sama atau hampir sama dengan model regresi berganda $\mathrm{Y}=\mathrm{a}+\mathrm{bX}_{1}+\mathrm{bX}_{2}$. Dari hasil analisa SPSS Versi 17 (Lihat: Lampiran) dapat dijelaskan bahwa $F$ hitung 102,477 lebih besar dari $F$ tabel atau juga nilai signifikansi untuk uji $F$ lebh kecil dari nilai alfa 0,05 yang artinya regresi mempunyai pengaruh yang sangat signifikan.

Dari hasil perhitungan dapat disimpulkan bahwa koefisien diterminasi 0,031 yang artinya disiplin kerja dan tunjangan kinerja daerah (TKD) dengan kinerja aparatur secara bersama-sama sebesar 3,1\%, melalui model persamaan regresinya. Kekuatan disiplin kerja dan tunjangan kinerja daerah (TKD) secara bersama-sama terhadap kinerja aparatur, membandingkan antara $r$ hitung dengan $r$ tabel maka diketahui bahwa 0,811 > 0,239, maka kekuatan korelasi keduanya memiliki cukup pengaruh yang signifikan.

Tabel 10

Hasil Perhitungan Uji Korelasi Product Moment dan t Hitung

\begin{tabular}{ccc}
\hline $\mathbf{N}$ & $\mathbf{r}$ (hitung) & Signifikansi $\mathbf{0 . 0 5}$ \\
\cline { 3 - 3 } 93 & 0,811 & $\mathbf{r}$ tabel \\
\hline
\end{tabular}

Pengujian ini menunjukkan adanya pengaruh yang sangat signifikan sedangkan kekuatan pengaruhnya hanya sebesar $3,1 \%$ hal ini juga berarti bahwa semakin baik disiplin kerja dan tunjangan kinerja daerah (TKD) secara bersama-sama maka semakin baik pula kinerja aparatur.

\section{PENUTUP}

bahwa:

Berdasarkan hasil dan pembahasan penelitian ini dapat di simpulkan

1. Disiplin Kerja mempunyai pengaruh yang signifikan terhadap kinerja aparatur di Dinas Pertanian Perkebunan dan Ketahanan Pangan serta Badan Lingkungan Hidup Kabupaten Pohuwato, hal tersebut dapat dilihat pada perhitungan korelasi product moment bahwa $r$ hitungnya adalah 0,811 pada taraf signifikansi (0.05) harga $r$ tabel sebesar 0,239 maka $r$ hitung $>$ dari $r$ tabel sehingga dapat disimpulkan adanya pengaruh yang sangat signifikan, adapun kekutan pengaruh berdasarkan kriteria interval koefisien $r$ hitung 0,811 tergolong kuat yang artinya pengaruh disiplin kerja terhadap kinerja aparatur di Dinas Pertanian Perkebunan dan Ketahanan Pangan serta Badan Lingkungan Hidup Kabupaten Pohuwato tergolong kuat. Sedangkan t hitung sebesar 0,957 dan dibandingkan t tabel sebesar 0,044 dengan taraf signifikansi (0.05) ternyata t hitung > dari t tabel dengan arti hipotesis diterima yang menyatakan adanya pengaruh yang sangat signifikan. 
2. Tunjangan Kinerja Daerah (TKD) mempunyai pengaruh yang signifikan terhadap Kinerja Aparatur di Dinas Pertanian Perkebunan dan Ketahanan Pangan serta Badan Lingkungan Hidup Kabupaten Pohuwato, hal tersebut dapat dilihat pada perhitungan korelasi product moment bahwa $r$ hitungnya adalah 0,922 pada taraf signifikansi (0.05) harga $r$ tabel sebesar 0,098 maka $r$ hitung $>$ dari $r$ tabel sehingga dapat disimpulkan adanya pengaruh yang sangat signifikan, adapun kekutan pengaruh berdasarkan kriteria interval koefisien $r$ hitung 0,922 tergolong kuat yang artinya pengaruh TKD terhadap Kinerja Aparatur tergolong sangat kuat. Sedangkan t hitung sebesar 0,957 dan dibandingkan $t$ tabel sebesar 0,044 dengan taraf signifikansi (0.05) ternyata $t$ hitung $>$ dari $t$ tabel dengan arti hipotesis diterima yang menyatakan adanya pengaruh yang sangat signifikan

3. Hubungan antara Disiplin Kerja dan Tunjangan Kinerja Daerah (TKD) secara bersama-sama mempunyai pengaruh yang signifikan terhadap Kinerja Aparatur di Dinas Pertanian Perkebunan dan Ketahanan Pangan serta Badan Lingkungan Hidup Kabupaten Pohuwato. Hal tersbut dapat dilihat pada kekuatan di siplin kerja dan tunjangan kinerja daerah (TKD) secara bersamasama terhadap kinerja aparatur, membandingkan antara $r$ hitung dengan $r$ tabel maka diketahui bahwa 0,811 >0,239, maka kekuatan korelasi keduanya memiliki cukup pengaruh yang signifikan.

Sedangkan saran yang diajukan oleh peneliti adalah sebagai berikut:

1. Perlu dibuat sentra-sentra pelatihan kerja upaya peningkatan keterampilan PNS sesuai dengan kebutuhan pada Dinas Pertanian Perkebunan dan Ketahanan Pangan serta Badan Lingkungan Hidup Kabupaten Pohuwato.

2. Diharapkan PNS lebih termotivasi lagi untuk meningkatkan kinerja mereka setelah adanya kedisiplinan dan tunjangan kinerja daerah (TKD).

3. Agar terus meningkatkan kinerja yang profesional serta berpartisipasi di dalam pengembangan dan pembangunan organisasi kedinasan.

4. Salah satu bentuk kegiatan pembinaan dan pengembangan kerja di Dinas Pertanian Perkebunan dan Ketahanan Pangan serta Badan Lingkungan Hidup Kabupaten Pohuwato dengan memfasilitasi semua kebutuhan guna meningkatkan kesejahteraan PNS.

\section{DAFTAR PUSTAKA}

Danim, S. 2006. Motivasi Kepemimpinan dan Efektivitas Kelompok. Jakarta: Rineka Cipta.

Doelhadi, 2001. Kerja Dalam Dimensi Tinjuan Psokologis.Jurnal Insan 3(1): 2740

Duncan, K. P. dan Smoot, T.D. 2004. Balas Jasa Berdasarkan Kinerja dalam Handbook Of Organizational Performance Analisis Perilaku dan Manajemen Editor C. Merle Johnson. William KK. Redmon, Thomas C. Mawhinney. Jakarta: PT. Rajagrafindo Persada.

Greenberg, J,. Baron, A.2003. Behavior Organizations. New Jersey: Pearson education, Inc.

Hasibuan, P. 2000. Manajemen SDM. Jakarta: Bumi Aksara. 
Keban, Yeremias T. 2004. Enam Dimensi Strategis Administrasi Publik: Konsep, Teori dan Isu. Yogyakarta: Gaya Media.

Mohi, E.M. 2013. Laporan Pertanggungjawaban kepada Masyarakat Gorontalo setelah 4 Tahun di DPD-RI. Gorontalo: Pustaka Gorontalo.

Muhammad, F. 2008. Reinventing Local Government. Jakarta: PT. Elex Media KomputindoKompas Gramedia.

Setyaka, H. 2014. Rahasia Kebiasaan Orang-Orang Sukses sejak Bangun Pagi hingga sebelum Sarapan. Yogyakarta: Diva Press.

Siagian P.S. 2004. Teori Motivasi dan Aplikasinya.Jakarta: PT. Rineka Cipta.

Suharsimi Arikunto, 2005. Manajemen Penelitian. Jakarta: Rineka Cipta.

Suwatno, H. Dan Priansa, D. 2011. Manajemen SDM dalam Organisasi Publik dan Bisnis. Bandung: Alfabeta.

Walgito, B. 2001. Pengantar Psikologi Umum. Yogyakarta: UGM.

Wibowo. 2008. Manajemen Perubahan. Jakarta: Rajawali Press.

Wijaya, C.S. 2014. 19 Menit Menaklukan Orang-Orang di sekitar Anda. Immortal Publisher. Universitas Gadjah Mada. Yogyakarta.

Wingfield, B. Dan Berry, J. 2006. Karyawan Unggul. Menghormati, Mengakui, Menghargai Karyawan untuk Mencapai Prestasi Terbaik. Jakarta: Rajawali Press. 